\title{
A Case of Large Cell Neuroendocrine Carcinoma in Posterior Supraglottis
}

\author{
Joon Pyo Hong $\mathbb{D}^{\mathbb{D}}$, Sang Hyun Kim, Sung Min Jin, and Sang Hyuk Lee $\mathbb{D}$ \\ Department of Otorhinolaryngology-Head and Neck Surgery, Kangbuk Samsung Hospital, \\ Sungkyunkwan University School of Medicine, Seoul, Korea
}

\section{성문 후상부에 발생한 대세포 신경내분비암종의 치료 1예}

홍준표 · 김상현 · 진성민 · 이상혁

성균관대학교 의과대학 강북삼성병원 이비인후과학교실

\author{
Received June 21, 2021 \\ Revised July 23, 2021 \\ Accepted August 3, 2021 \\ Address for correspondence \\ Sang Hyuk Lee, MD, PhD \\ Department of Otorhinolaryngology- \\ Head and Neck Surgery, \\ Kangbuk Samsung Hospital, \\ Sungkyunkwan University \\ School of Medicine, \\ 29 Saemunan-ro, Jongno-gu, \\ Seoul 03181, Korea \\ Tel $+82-2-2001-2269$ \\ Fax $+82-2-2001-2273$ \\ E-mail sh999.lee@samsung.com
}

Neuroendocrine carcinoma (NEC) is a rare form of hormone-secreting tumor. NECs originate from the epithelial cells of the larynx and account for less than $1 \%$ of the laryngeal neoplasm. Most cases of NECs are diagnosed by pathological confirmation after surgery. The terminology of laryngeal NEC has been a source of confusion. In 2017, World Health Organization newly categorized laryngeal NEC; as a result, the large cell type, which has been the main target of disagreement, was finally included into a subtype of poorly differentiated NEC. We report a case of a 58-year-old male with a growing granulomatous mass in the posterior supraglottis. The granuloma was removed by surgical excision when the size of the mass increased. He was diagnosed with the large cell type laryngeal NEC by pathological confirmation. He underwent postoperative radiotherapy and is currently being followed up in our outpatient clinic without evidence of recurrence.

Korean J Otorhinolaryngol-Head Neck Surg 2022;65(3):164-8

\section{서 론}

후두의 신경내분비종양(neuroendocrine tumor)은 과거 카 르시노이드 종양(carcinoid tumor)으로 불렸으며 후두에서 발생하는 종양의 $1 \%$ 이하를 차지하는 것으로 알려진 드문 형태의 종양이다. 1955년 Blanchard와 Saunder가 첫 증례를 보고한 이후 1969년 Goldman이 carcinoid라는 용어를 사 용하였으며, 1983년 Duvall이 처음으로 분화도 차이에 따른 분류를 제시하였다.

그동안 신경내분비종양의 분류는 통일되지 않고 저자들에 따라 여러 분류법들이 혼용되어 사용되어 왔지만, 2017년

This is an Open Access article distributed under the terms of the Creative Commons Attribution Non-Commercial License (https://creativecommons.org/licenses/by-nc/4.0) which permits unrestricted non-commercial use, distribution, and reproduction in any medium, provided the original work is properly cited.
World Health Organization (WHO)가 악성 종양의 기원에 따라 상피성(epithelial)인 경우 신경내분비암종(carcinoma), 신경성(neural-type)인 경우 부신경절종(paraganglioma)으 로 명명하였고, 이 중 신경내분비암종은 조직학적 분화도에 따라 고분화도(well-differentiated), 중분화도(moderatelydifferentiated), 저분화도(poorly-differentiated)로 구분하면 서 현재의 통일된 분류법을 이용하게 되었다. 그동안 분류에 논란이 되었던 대세포(large cell type) 신경내분비암종의 경 우 소세포(small cell type)와 함께 저분화도 암종의 아형으 로 구분되었다. ${ }^{1)}$

후두의 신경내분비종양은 다양한 임상 증상으로 발현되며, 연하곤란, 애성, 인후통 등을 동반한 성문 상부 종물로 발생 하는 것이 가장 흔하고, 이 외 경부, 후두개 등에서 발생한 사 례들이 보고된 바 있다. ${ }^{2-4)}$ 신경 내분비종양의 확진에는 병리 
조직학적 검사가 필수적이며, 종양의 근치적절제가 권고된다. 저분화도 암종의 경우 술후 항암 혹은 방사선 치료를 추가하 는 것이 권고되며, 5 년 생존률은 조직학적 분화도에 따라 $20 \%$ 에서 $60 \%$ 까지 다양하게 보고되고 있다. ${ }^{4)}$

저자들은 성문 후상부에 발생하였던 육아종성 종물에 대 하여 수술적 제거 후 조직학적 검사상 후두의 대세포 신경내 분비암종으로 확진된 1예를 치험하였기에 이를 문헌 고찰과 함께 보고하는 바이다.

\section{증 례}

58세 남자 환자가 2달 전부터 발생한 목 안 불편감으로 본 원 이비인후과에 내원하였다. 후두 내시경 검사를 시행하였 고 우측 성문 후상부에서 기원하는 약 $2 \mathrm{~cm}$ 크기의 육아종 성 종물이 관찰되었다. 종물은 피열연골의 내측 점막과 연결 되어 있었고 성문의 전상부로 돌출되어 있었다. 성대의 움직 임은 정상이었으며 피열 연골 사이 점막의 경미한 비후 소견 이 관찰되었다(Fig. 1A), 저자들은 우선 양성 종양 의심하에 보존적 치료를 하며 주기적인 경과 확인을 계획하였으며, 후 두 내시경 소견의 변화나 증상 악화 시 정확한 진단을 위한 조직검사를 시행하기로 하였다. 또한 비전형적인 형태의 접 촉성 육아종의 가능성을 고려하여 양자 펌프 억제제(proton pump inhibitor) 투여를 시작하였다.

2개월간의 양자 펌프 억제제 투여 후 주관적인 목 불편감 의 호전은 있었으나 후두의 종물은 크기 및 형태의 변화 없이 유지되는 소견을 보였다. 양자 펌프 억제제를 변경하여 2개 월간 추가 투여하였으나 증상의 완전한 소실이나 후두내시경 상 종물의 변화는 없었고, 진단을 위한 조직학적 검사를 권유 하였으나 환자 개인적인 사정으로 추가적인 치료를 거부한 후 외래에 내원하지 않았다(Fig. 1B).

1 년 후 환자는 악화된 목 안의 불편감을 주소로 재내원하
였다. 후두 내시경 검사상 이전과 동일한 위치에 보였던 육아 종성 종물의 크기가 증가하면서 전상방으로 더욱 돌출되어 있었으며, 종물에 의하여 성문 일부가 폐쇄되었고 우측 성대 의 움직임 저하가 관찰되었다(Fig. 1C). 이에 종양 세포가 피 열돌기나 성대 내근, 되돌이 후두 신경 등의 주변 구조물들로 침범한 것으로 판단되었고, 악성종양 여부 확인을 위한 조직 학적 검사가 필요할 것으로 사료되어 현수후두경하 후두 수 술을 계획하였다. 수술 전 시행한 경부 컴퓨터단층촬영(CT) 검사상 우측 진성대의 피열연골 부근에 약 $1.8 \mathrm{~cm}$ 크기의 조 영되는 종괴가 관찰되었고 이 외 경부 림프절의 비대나 갑상 선, 폐의 병변은 보이지 않았다(Fig. 2).

전신마취하 시행된 후두 수술 중 우측 피열 연골부에서 기 시한 $2 \mathrm{~cm}$ 크기의 육아종성 종양이 관찰되었다. 종양의 일부 절제 후 수술 중 동결절편 검사를 통하여 악성이 의심되는 소 견을 얻었고, 이에 $\mathrm{CO} 2$ laser를 이용한 종양의 완전 절제를 시행하였다. 종물은 비교적 주변 구조물과 박리가 수월하였 고, 피열연골의 성대 돌기와 갑상피열근을 포함한 성문의 후 방부를 절제하였다. 종양의 경계로부터 2-3 mm의 안전역을 확보하였고, 수술 중 출혈량은 많지 않았으며 절제연에서 복 수의 동결절편 검사를 추가로 시행하여 악성종양이 없음을 확인하였다.

수술 후 조직검사 결과상 전반적인 세포 핵의 크기 증가와 뚜렷한 인(nucleoli) 소견이 관찰되었다. 종양 세포에는 피열 연골의 소타액선 침범과 조직 내 림프 및 신경의 침범 소견도 관찰되었다. 면역조직화학 검사상 calcitonin에서 양성을 보 였고, $\mathrm{Ki}-67$ 에서는 7\%-10\% 양성을 보였다(Fig. 3). 추가로 시행한 염색에서 synaptophysis, CK and CD 56, TTF-1에서 양성, chromongranin 염색은 약양성, S-100 and LCA, p63, $\mathrm{CEA}$ 에서는 음성 소견이 보여 최종적으로 후두의 대세포 신 경내분비암종으로 진단되었다.

환자는 특별한 합병증 없이 수술 후 3일째에 퇴원하였다.
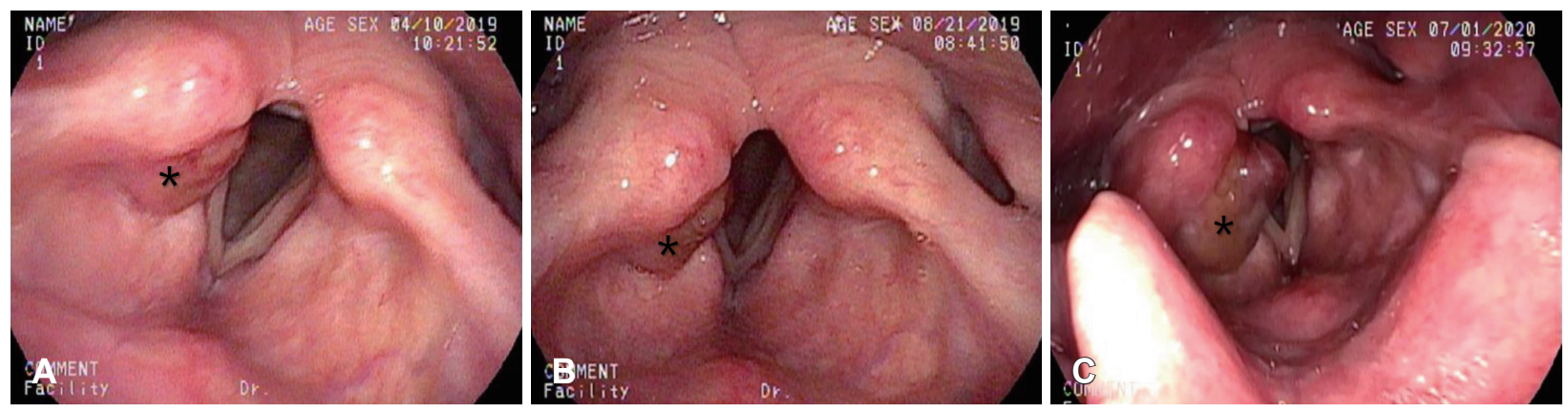

Fig. 1. Preoperative laryngoscope finding. A: About $2 \mathrm{~cm}$ sized round granulomatous mass was originated from the posterior superior area of supraglottis (astrix). The mass was protruded to the anterosuperior area. The surface was smooth and there was slight erythematous change. B: Rt arytenoid mass after 4 months of proton pump inhibitor. There was no interval change of mass. C: After 1 year of follow-up loss, there was an increased size of the mass. Partial glottal obstruction and decreased mobility of Rt vocal fold was observed. 
수술 후 3일째 시행한 후두 내시경 검사상 종양은 잘 절제되 어 있었고, 우측 성대 부종 및 성대 움직임의 저하 소견이 보 였다(Fig. 4). 병기설정을 위해 흥부와 복부 컴퓨터단층촬영, 양전자방출 컴퓨터단층촬영을 시행하였으며, 양전자방출 컴
퓨터단층촬영상 우측 경부 3,4 구역 림프절에 경미한 섭취증 가 소견이 보여 중심침생검을 시행하였으나 전이는 확인되지 않았다. 수술 2주 후 시행한 calcitonin은 $7.82 \mathrm{pg} / \mathrm{mL}$ 로 정상 수치를 보였다. 다학제진료를 통해 수술 후 방사선 치료가 결
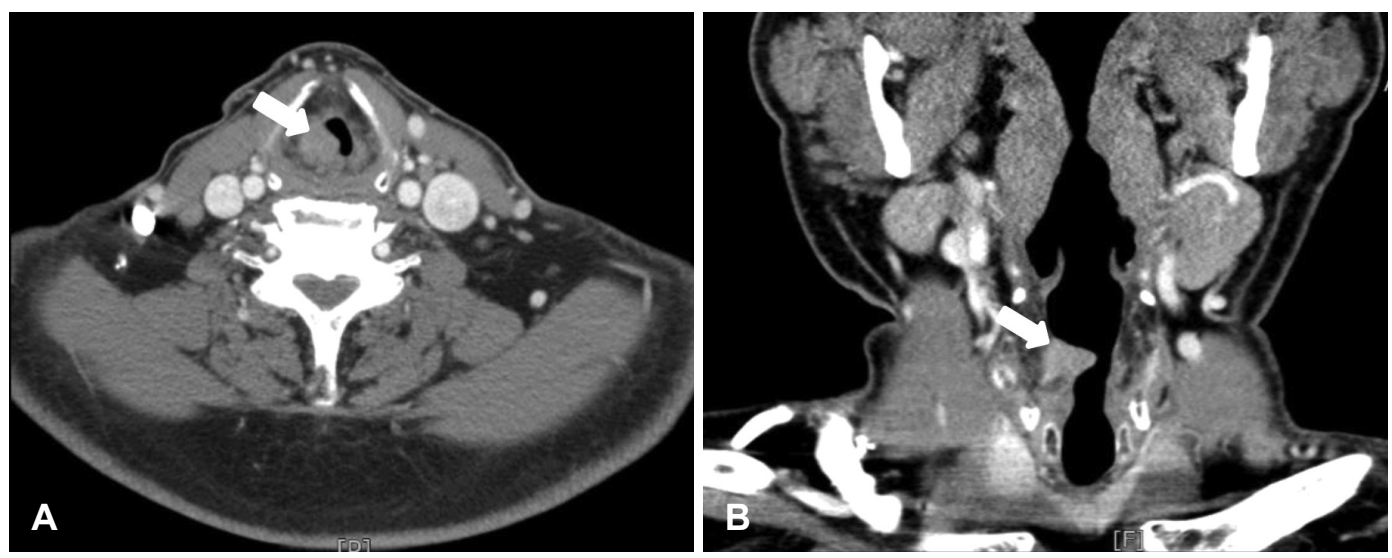

Fig. 2. Preoperative axial (A) and coronal (B) CT image. There was a $1.8 \times 1.6 \mathrm{~cm}$-sized enhancing nodular lesion in Rt arytenoid cartilage (arrow).
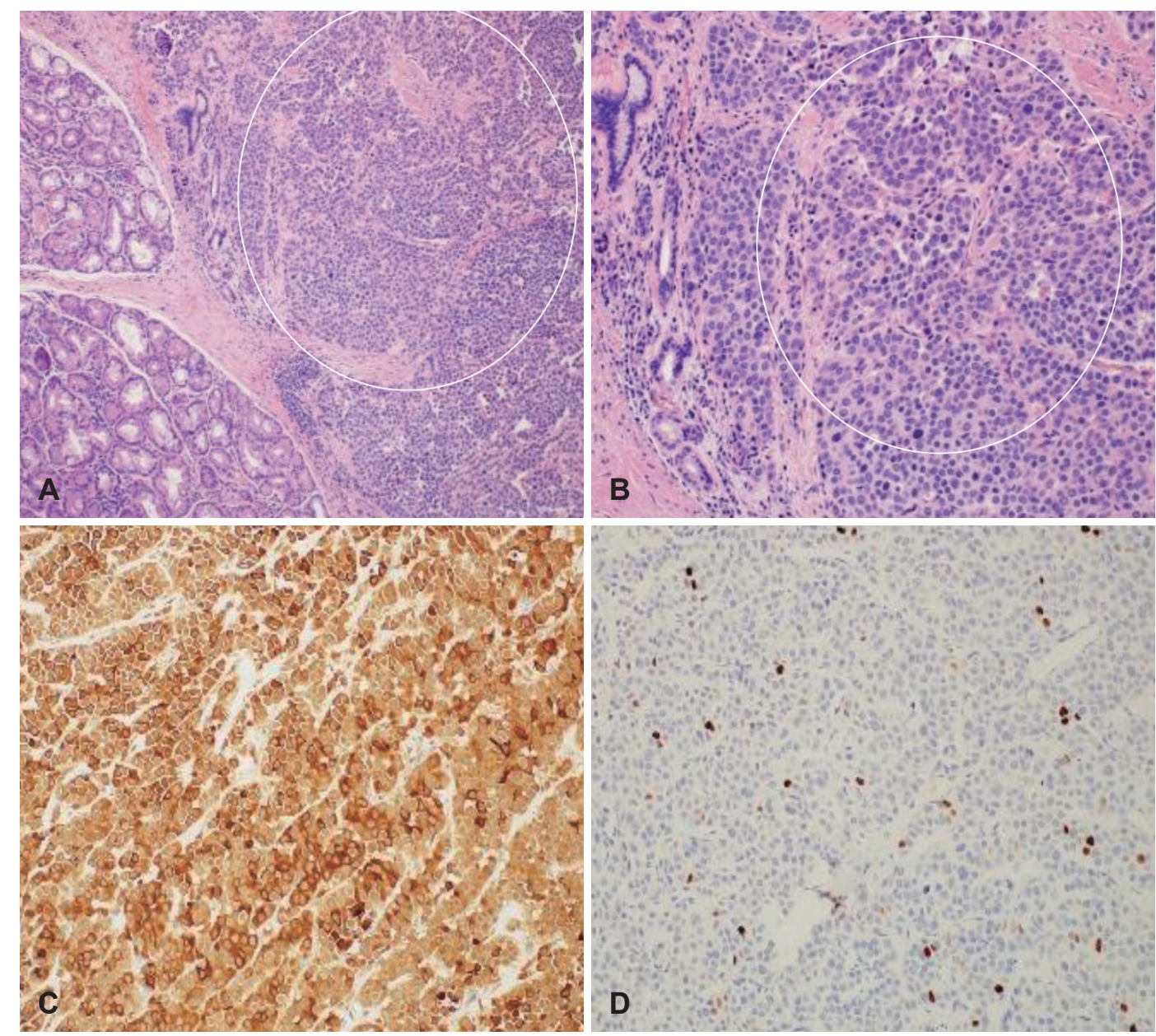

Fig. 3. Pathologic finding. A: There was no obvious organoid pattern (circle) with normal minor salivary gland $(H \& E, \times 100)$. B: Large sized nuclei with fine chromatin and occasional prominent nucleoli (circle, H\&E, $\times 200)$. (C) Immunohistochemical staining of calcitonin stain were diffusely positive (D) Ki-67 positive index was 7\%-10\%. H\&E, hematoxylin and eosin. 
정되어 시행 받았으며, 수술 후 1 년째 시행한 후두 내시경 검 사에서 우측 성대 움직임의 경미한 저하와 방사선 치료로 인 한 좌측 피열 후두개 주름부의 점막 부종 외에 특이 소견은 관찰되지 않았다(Fig. 5). 환자는 수술 후 1년 이상 calcitonin 수치의 상승 소견을 보이지 않고 있으며, 재발의 증거 없이 본원 외래에서 경과 관찰 중이다.

\section{고 찰}

후두에 발생하는 신경내분비종양의 분류는 꾸준히 개정되 어왔으며, 본 증례와 같은 대세포 신경내분비암종의 경우 2017년 WHO가 후두 신경내분비암종에 대한 개정된 분류안 을 제시하기 전까지는 비정형 카르시노이드(atypical carcinoid) 타입 중 하나로 포함되었었으나, 조직학적으로 다른 비 정형 카르시노이드 종양들과 뚜렷한 차이를 보였고 병의 예 후도 더 좋지 않아 2017년 개정안에서는 소세포(small cell) 내분비암종과 함께 저분화도의 아형으로 구분되었다. ${ }^{1,5)}$

신경내분비암종에서 권고되는 치료 방법은 종양의 분류에

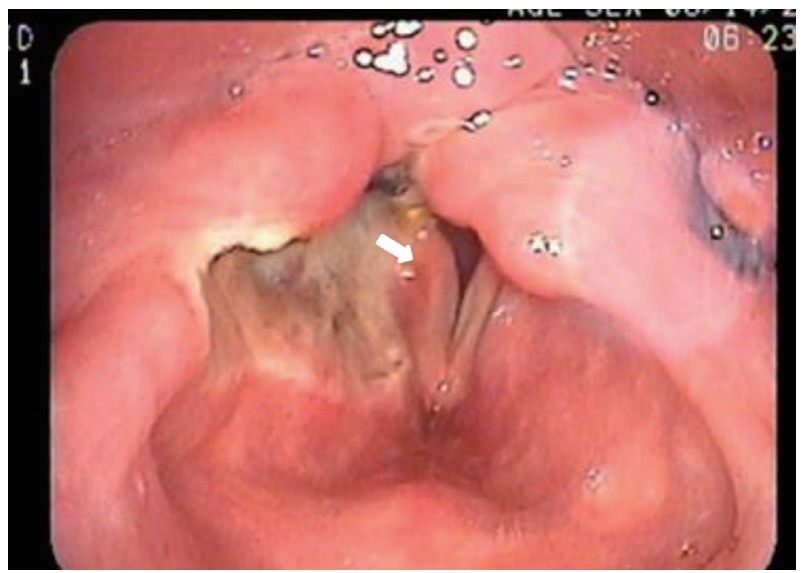

Fig. 4. Clear resection of the tumor was seen. There was an edematous change in Rt vocal fold (arrow) with decreased mobility.
따라 차이가 있어왔다. 2015년 436건의 후두의 신경내분비암 종 사례에 대해 시행한 메타 분석에 따르면 일반적인 비정형 카르시노이드 종양의 경우 근치적인 수술적 절제가 필요하며 양측 경부 2,3 구역 경부절제술이 종양의 재발 방지에 도움이 되고, 술후 방사선 치료는 도움이 되지 않는다고 하였다. 그 러나 대세포 신경내분비암종의 경우 비정형 카르시노이드 종 양과 별개로 구분하였으며, 당시 $\mathrm{WHO}$ 분류법의 한계로 인 해 대세포 신경내분비암종만의 발생률을 파악하는 것이 불 가능해 분석에 제한이 있었지만, 병의 임상양상을 고려해 보 았을 때 소세포 암종의 경우와 같이 항암 방사선 치료를 권 유하였다. ${ }^{5)}$ 한편 2005년 Gillenwater 등6)은 비정형 카르시노 이드 종양 환자들에 대해 수술 단독 치료, 수술 후 항암치료, 수술 후 방사선 치료, 항암 방사선 단독 치료 등 여러 방법으 로 치료를 시도하였던 결과들을 비교 분석해 보았을 때 보존 적 후두 수술 후 방사선 치료를 시행하는 것만으로도 전통적 인 광범위 후두 절제술과 비교하여 열등하지 않은 치료 결과 를 얻을 수 있다고 주장하였다. ${ }^{6}$

이처럼 비정형 카르시노이드 종양의 치료는 저자들에 따라 다양하게 시도되어 왔으며 2017년 WHO의 후두신경내분비 암종 분류 개정안에서 기존 비정형 카르시노이드에 포함되었 던 대세포 신경내분비암종을 별개의 아형으로 새롭게 분류 하면서, 대세포 신경내분비암종의 치료 가이드라인 또한 새 롭게 정립이 필요한 상황이다. 저자들은 술후 후두기능을 최 대한으로 보존하기 위해 CO2 laser를 이용한 국소 절제를 시 행하였으며, 술후 방사선 치료를 통해 저분화도 종양의 재발 을 막고자 하였다. CO2 laser를 이용한 경구강 후두 내 신경 내분비암종의 절제는 과거에도 성문 상부의 비정형 카르시노 이드 종양의 제거를 위해 광범위 후두 절제 술식을 대신하여 사용된 적 있었던 방법이며,8) 항암치료는 수술의 효과가 제 한적인 소세포 신경내분비암종에 한해서 주로 이용되었었기 때문이다. ${ }^{9)}$
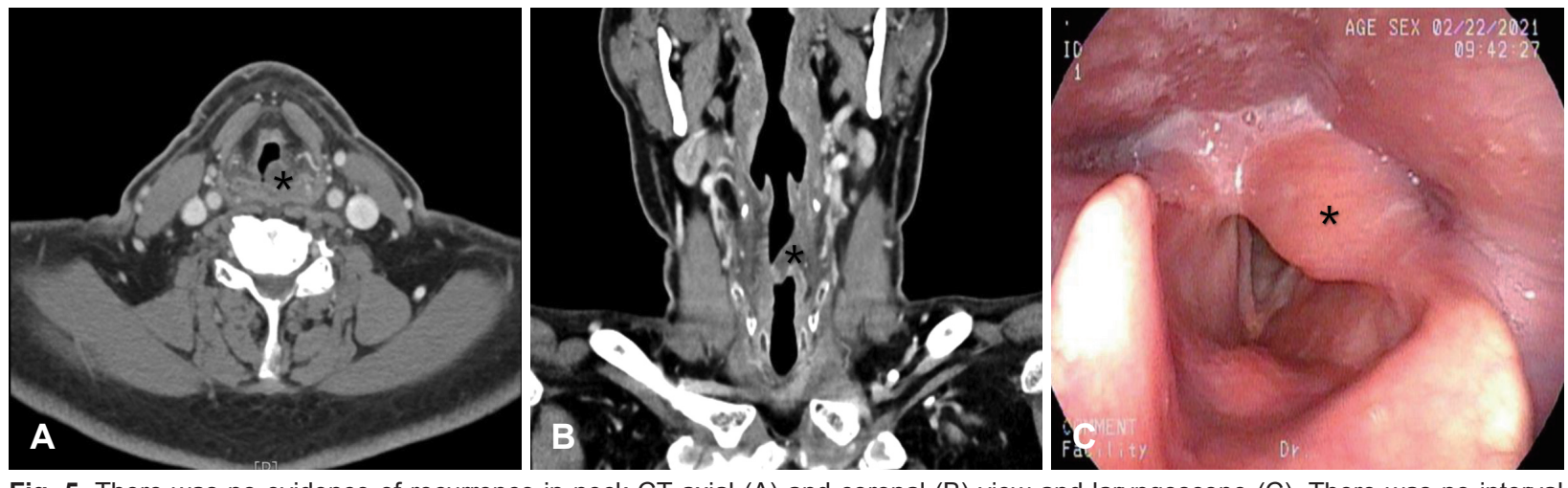

Fig. 5. There was no evidence of recurrence in neck CT axial (A) and coronal (B) view and laryngoscope (C). There was no interval change of decreased mobility in Rt vocal fold compared to postoperative laryngoscope. Diffuse thickening of soft tissue in Lt aryepiglottic fold (astrix) was seen, interpreted as post-radiation treatment change. 
저자들은 2017년 WHO가 후두 신경내분비종양의 분류 개 정안을 발표 이후 대세포 신경내분비암종의 치료 방법에 대 한 가이드라인이 부재한 상황에서, 기존에 국내에 보고된 바 없던 성문 후상부에 발생한 대세포 신경내분비암종을 $\mathrm{CO} 2$ laser를 통한 국소 절제 및 술후 방사선 요법을 통해 치험하 였기에 문헌 고찰과 함께 보고하는 바이다.

\section{Acknowledgments}

None.

\section{Author Contribution}

Conceptualization: all authors. Formal analysis: Sang Hyun Kim, Hye Soo Kim, Sung Min Jin. Investigation: Joon Pyo Hong. Resources: Joon Pyo Hong, Sang Hyun Kim, Sung Min Jin. Supervision: Sang Hyun Kim, Hye Soo Kim, Sung Min Jin. Writing-original draft: Joon Pyo Hong. Writing - review \& editing: Joon Pyo Hong, Sang Hyuk Lee.

\section{ORCIDs}

Sang Hyuk Lee https://orcid.org/0000-0003-4412-3486 Joon Pyo Hong

\section{REFERENCES}

1) Gale N, Poljak M, Zidar N. Update from the 4th edition of the World Health Organization classification of head and neck tumours: What is new in the 2017 WHO Blue Book for tumours of the

hypopharynx, larynx, trachea and parapharyngeal space. Head Neck Pathol 2017;11(1):23-32.

2) Lee YS, Kim KI, Kim HD, Kwon YJ. Neuroendocrine tumors of the larynx: Four cases. Korean J Otolaryngol-Head Neck Surg 2004;47(12):1337-43.

3) Lewis JS Jr, Spence DC, Chiosea S, Barnes EL Jr, BrandweinGensler M, El-Mofty SK. Large cell neuroendocrine carcinoma of the larynx: Definition of an entity. Head Neck Pathol 2010;4(3):198207.

4) Ghosh R, Dutta R, Dubal PM, Park RC, Baredes S, Eloy JA. Laryngeal neuroendocrine carcinoma: A population-based analysis of incidence and survival. Otolaryngol Head Neck Surg 2015; 153(6):966-72.

5) van der Laan TP, Plaat BE, van der Laan BF, Halmos GB. Clinical recommendations on the treatment of neuroendocrine carcinoma of the larynx: A meta-analysis of 436 reported cases. Head Neck 2015;37(5):707-15.

6) Gillenwater A, Lewin J, Roberts D, El-Naggar A. Moderately differentiated neuroendocrine carcinoma (atypical carcinoid) of the larynx: A clinically aggressive tumor. Laryngoscope 2005;115(7): 1191-5.

7) Chang KP, Lee LY, Yeh AR, Dai TS, Hao SP. Endoscopic CO2 laser surgery for an atypical carcinoid tumor of the epiglottis masquerading as a supraglottic cyst. Head Neck 2005;27(11):1004-7.

8) Piazza C, Giudice M, Berlucchi M, Peretti G, Antonelli AR. Atypical carcinoid tumour of the larynx treated with $\mathrm{CO} 2$ laser excision: Case report. Acta Otorhinolaryngol Ital 2003;23(1):43-6.

9) Ferlito A, Silver CE, Bradford CR, Rinaldo A. Neuroendocrine neoplasms of the larynx: An overview. Head Neck 2009;31(12): 1634-46. 